\title{
Histamine-2 Receptor Antagonist
}

National Cancer Institute

\section{Source}

National Cancer Institute. Histamine-2 Receptor Antagonist. NCI Thesaurus. Code C29702.

Any agent that competitively binds to and blocks the histamine $\mathrm{H} 2$ receptors found in the stomach, heart, uterus, on vascular smooth muscle and in the central nervous system (CNS). Of particular clinical relevance is the blockage of $\mathrm{H} 2$ receptors found on the parietal cells of the stomach, which prevents gastric acid secretion. 